\title{
\begin{tabular}{ll}
\hline 臨 \\
\hline
\end{tabular} \\ 対話方式による語音聴力検査法 \\ 宮田 耕志 ${ }^{1)}$ - 庄司 和彦2) - 児嶋 久剛(2) \\ 大森 孝一3) . 平野滋 2 ・ 篠原 尚吾4) \\ Interactive Speech Audiometry
}

\author{
Koji Miyata \\ (Nagahama Red Cross Hospital) \\ Kazuhiko Shoji, Hisayoshi Kojima and Shigeru Hirano \\ (Kyoto University) \\ Koichi Omori \\ (Nishi Kobe Medical Center) \\ Shogo Shinohara \\ (Kobe City General Hospital)
}

Speech discrimination and hearing aid performance in patients with hearing loss have been evaluated by speech audiometry where a tape or CD is utilized as a sound source. Since all sound samples in a list on the tape or $\mathrm{CD}$ are consecutively presented to the examinee, this conventional method provides the perception rate of the whole list. It has been difficult however, to evaluate the perception of a specific sound in the list.

We developed a new method of interactive speech audiometry. Using this method, the patient's response to each sound sample can be monitored at any required sound level. All sound samples such as the 5 vowels, 13 consonant-vowel syllables, and sentences are stored in a computer as sound files. Any sound sample can be randomly selected to present to the examinee, who replies verbally. Interactive speech audiometry can provide a more accurate evaluation of speech discrimination in patients with hearing loss.

Key words : speech audiometry, interactive examination, computer

はじめに

従来より難聴者の語音聴取能の評価や補聴器の装用効 果判定には，57式あるいは67式語音表が多く用いられ， テープやコンパクトディスク $(\mathrm{CD})$ を使って語音弁別検 査が行われている12). しかし，この方法は，テープや
CD を音源とするがゆえに，1リストあたり50あるいは 20の検査音が連続して被検者に呈示され，検査音ごとの 評価が困難となっている。 また, 検査音が一定間隔で次 次に呈示されるため, その速度についていけず, 高齢者 や小児には検査が困難な場合がある。そこで，今回われ
1）長浜赤十字病院耳鼻咽喉科

3）西神戸医療センター耳鼻咽喉科
2) 京都大学大学院医学研究科 感覚運動系病態学講座 聴覚・言語病態学領域

4）神戸市立中央市民病院耳鼻咽喉科 
われは, 純音聴力検査と同様に検査音の選択と呈示する 音圧が自由に設定でき, 呈示された検查音に対する被検 者の答えの正誤をそのつど判定できる, 対話式語音聴力 検查法を考案したので，その成績を予報的に報告する．

\section{方 法}

\section{1. 検査音の選択}

検査音として, 母音弁別能, 子音弁別能を評価する目 的で単音節を選択した。すなわち，母音弁別能をみるた めの 5 母音と, 子音并別能をみるための後続母音を

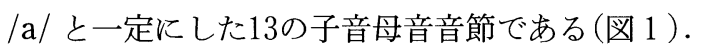

2 . 検查音の作成方法

男性アナウンサー (27歳)が防音室で発声した単音節の 音声を, 口前約 $20 \mathrm{~cm}$ のマイクロフォン (SONY ECM 959) で, DAT レコーダ (DENON DTR-100P) に録音し た。これをDigidesign 社の Sound tools II を使用して コンピュータ (Macintosh ${ }^{\circledR}$ Quadra 950) のハードディス クに記録した。各検査音に対し, 最大音圧をあわせる目 的で音声波形の最大振幅部を連続させた音声ファイルを

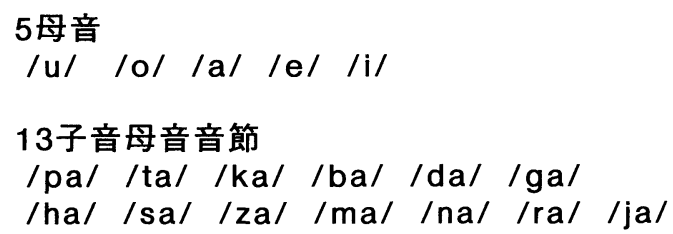

図 1 検査に用いた単音節のリスト
それぞれ作成し，作成した各検査音の音圧が被検者の耳 の位置で同じになるように音圧の校正を行い，単音節の 検查音のセットを作成した。これらをサンプリング周波 数 $44.1 \mathrm{kHz}$ のサウンドファイルとしてノート型パーソ ナルコンピュータ (Macintosh ${ }^{\circledR}$ Power Book 520) に保存 した。図 2 は, 単音節の検査を実際に行っているコンピ ュータ画面で, 単音ひとつひとつが音声ファイルになっ て怙り，アイコンを選択してダブルクリックするだけで 検查音が呈示される。

\section{3 . 検查方法}

このシステムの使用方法は, 図 3 右のように, コンピ ュータを補聴効果測定装置 (RION HF-03) の外部入力に 接続し, スピーカから検査音を呈示すると, 防音室での 補聴器装用効果の判定や人工内耳術後患者の語音聴取能 の評価が行える。 また, 図 3 左のように, オージオメ一 タに接続し、ヘッドホンから検查音を呈示すれば，従来 の語音検查と同じように片耳ごとの語音聴取能を測定す ることができる。いずれにしても，コンピュータ上で検 査音を自由に選択して, 補聴効果測定装置あるいはオー ジオメータで音圧を自由に变えて検査音を呈示できる． 呈示された各検査音に対し, 被検者は呈示ごとに答光, 正誤はそのつど検者が判定し, 純音聴力検査のような対 話式の語音検査が可能となっている.

\section{症例呈示}

実際に本法を用いて検査を行った症例を示す.

症例 1.86歳, 男性で, 両感音性難聴である. 四分法 による平均聴力は, 右が $70 \mathrm{~dB}$, 左が $58 \mathrm{~dB}$ であった.

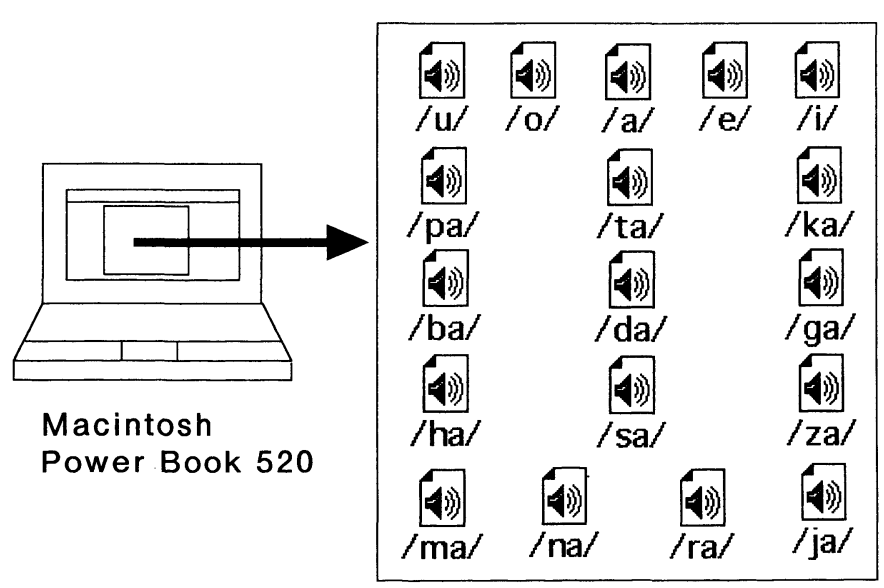

図 2 単音節検査中のコンピュータ画面 


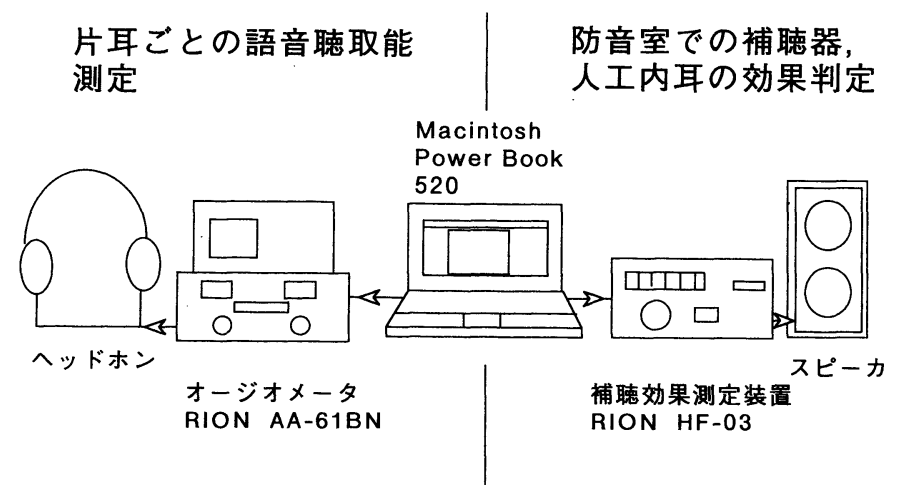

図 3 システムの使用方法

左耳に補聴器を装用した状態で, 防音室にてスピーカか ら検査音を呈示し, 語音の聞き取りを調べた(図 4)。単 音節の下には, 各呈示音圧での被検者の回答を記してあ る. 検査の結果, 5 母音はすべて并別可能であり，13子 音母音音節中 8 音節が認知可能であった。無声破裂音や

5 母音

\begin{tabular}{|c|c|c|c|c|c|}
\hline 呈示音厓(dB) & $/ \mathrm{u} /$ & $10 /$ & $\mid \mathrm{a} /$ & /e/ & $/ \mathrm{i} /$ \\
\hline 70 & $\mathrm{u}$ & 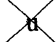 & $a$ & $(\mathrm{e})$ & (i) \\
\hline 80 & & 0 & & & \\
\hline 90 & & & & & \\
\hline
\end{tabular}

\section{3 子音母音音節}

\begin{tabular}{|c|c|c|c|c|c|c|}
\hline 呈示音压(dB) & $/ \mathrm{pa} /$ & $/ \mathrm{ta} /$ & $/ \mathrm{ka} /$ & $/ \mathrm{ba} /$ & $/ \mathrm{da} /$ & $/ \mathrm{ga} /$ \\
\hline 70 & $\pi$ & 2 & $\mathrm{ka}$ & a & 12 & $\not$ \\
\hline 80 & $x$ & ta & & 12 & 12 & \\
\hline 90 & $x$ & & & 10 & 12 & $\mathrm{ga}$ \\
\hline
\end{tabular}

\begin{tabular}{|c|c|c|c|c|c|c|c|}
\hline 呈示音E(dB) & /ha & /sa/ & /za/ & $/ \mathrm{ma} /$ & $/ \mathrm{na} /$ & $/ \mathrm{ra} /$ & $/ \mathrm{ja} /$ \\
\hline 70 & 12 & sa & 72 & a & $a$ & 82 & $\mathrm{ja}$ \\
\hline 80 & a & & $\mathrm{za}$ & 2 & 12 & $\mathrm{ra}$ & \\
\hline 90 & ha & & & $d a$ & 82 & & \\
\hline
\end{tabular}

図 4 症例 1 の検査結果 図中の○は正答，×は誤答を示す.
摩擦音は汪とんど認知できる一方で, 有声破裂音は $/ \mathrm{ra} /$ 亿異聴する傾向があり, 鼻音は有声破裂音に異聴 することがわかる。

症例 2.57歳, 男性で, 両感音性難聴である. 四分法 に上る平均聴力は, 右が $91 \mathrm{~dB}$, 左が $90 \mathrm{~dB}$ であった. 裸耳では, $90 \mathrm{~dB}$ の音圧で検査音を呈示しても，すべて 認知できず，左右それぞれに補聴器を使用したときの語 音聴取能を同様の方法で比較した(図 5 )。単音節の下に ある数值は，正答が得られたときの呈示音圧で， $90 \mathrm{~dB}$ での呈示でも正答が得られなかった検查音については,

5 母音

\begin{tabular}{|c|c|c|c|c|c|}
\hline & $/ \mathrm{u} /$ & $/ \mathrm{o} /$ & $/ \mathrm{a} /$ & $/ \mathrm{e} /$ & $/ \mathrm{i} /$ \\
\hline 補聴器右耳装用 & 70 & 80 & 70 & 0 & $\mathrm{o}$ \\
\hline 補聴器左耳装用 & 70 & 70 & 70 & 0 & $\mathrm{u}$ \\
\hline
\end{tabular}

13 子音母音音節

\begin{tabular}{|c|c|c|c|c|c|c|}
\hline & $/ \mathrm{pa} /$ & $/ \mathrm{ta} /$ & $/ \mathrm{ka} /$ & $/ \mathrm{ba} /$ & $/ \mathrm{da} /$ & $/ \mathrm{ga} /$ \\
\hline 補聴器右耳装用 & 80 & 70 & 80 & ta & 80 & 80 \\
\hline 補聴器左耳装用 & $\mathrm{sa}$ & 70 & ta & ta & 90 & $\mathrm{da}$ \\
\hline
\end{tabular}

\begin{tabular}{|c|c|c|c|c|c|c|c|}
\hline & $/ \mathrm{ha} /$ & $/ \mathrm{sa} /$ & $/ \mathrm{za} /$ & $/ \mathrm{ma} /$ & $/ \mathrm{na} /$ & $/ \mathrm{ra} /$ & $/ \mathrm{ja} /$ \\
\hline 補聴器右耳装用 & ta & ta & ya & ba & 90 & ya & ya \\
\hline 補聴器左耳装用 & ka & ka & ya & na & 90 & ya & ya \\
\hline
\end{tabular}

図 5 症例 2 の検查結果 
得られた被検者の回答を記してある。この結果をみると， 語音認知という点では子音の并別が相対的によい右耳の 方が装用耳として適しているといえる。また, 左右とも， 無声音は無声音に異聴していることがわかる. 今回の対 話方式による語音検査では, このように，母音，子音の なにが認知可能でななが認知できなかったかといらこ とや，どのように異聴したかといらことまで，容易に検 討することができる.

\section{考察}

現在, 語音弁別検査は, テープやュンパクトディスク (CD) を用いて行われることが多い。テープでは57式あ るいは67式語音表の単音節が，CD では57式語音表や, 57式語音表とほぼ同じ単音節を含む補聴器適合評価用 CD (TY-89 ${ }^{344)}$ が現在使用可能であるが，いずれの方法 でも, 被検者は呈示された検査音に対して筆記にて回答 し, 検査結果は回答用紙の回収後に, 各呈示音圧で単音 節認知が 1 リスト内で何パーセントであったかといらこ とで表わされてきた。 この方法では，検査音に対する反 応をそのつど確認することができない，連続呈示である ため被検者が検査のスピードについていけないといらこ とがあり得るのに加えて，どの単音がわからないために 聞き取りが悪いのかといった質的評価が困難であった。 実際, テープや CD のなかの語音表にはパ行 5 音節がは いっていないが(1224)5)，これは，検査音が日本語語音の 出現頻度を参考に選定されているためで，このことから も語音表自体が個別の語音の検査を目的としたものでな いことがわかる。

竹内 ${ }^{6)}$ の発表した, 自動語音聴力検査装置 : CASA (computer-aided speech audiometer) は, 被検者の負担 を軽減し，検査結果の判定を容易にするために開発され たシステムである。これは，CRTディスプレイに表示 された 5 つの単音節の選択肢の中から, 被検者が聞き取 った単音節を直接タッチスクリーンに触れて回答する. 検査は患者の応答があってから次の検査に進むため反応 が遅くとも検查が可能で, 同じ検查音を繰り返し呈示で きるし, 検査終了後の結果の判定や集計も容易である.

しかし, このシステムでも全部で20音節の検査が順に行 われるため，そのなかの一部を自由にとりだすことが難 しい点は同じであった。

今回考案した語音聴力検查法は, 使用する各検查音を 音声ファイルとして個別にコンピュータ上に保存するこ
とで，検査音を検者が自由に選択することを可能にした。 これにより，選択された各検査音を，検査ごとに音圧を 自由に変えて呈示することができ，呈示ごとに被検者の 反応を知ることができる。いわば，純音聴力検査と同じ ように対話式に語音認知を調べることができるのである. このシステムは, 音圧を校正する手間はあるものの検査 したいと思う音源を自由に搭載できる点でも優れて和り， 日常の会話聴取能力を反映させるものとして日本語の有 意味短文を検查音として用いることも可能である7). 大 がかりな機器を要さない点でも有用と思われる.

$$
\text { まとめ }
$$

対話方式による語音聴力検査法を考案した。この方法 により，従来困難であった難聴者の語音聴取能の質的評 価が容易となった。

稿を終えるにあたり，御校閲頂きました京都大学大学院医学 研究科 感覚運動系病態学講座 聴覚・言語病態学領域, 本庄 㦑教授に深謝いたします。

本論文の要旨は, 第 58 回耳鼻咽喉科臨床学会 (平成 8 年 6 月 28 日, 名古屋市) 抽よび第 41 回日本聴覚医学会 (平成 8 年 10 月 3 日，京都市)に执いて口演した。

な拉，本研究の一部は，大阪ガスグループ福祉財団による助 成を受けた。

\section{参考文献}

1) 佐藤恒正: 語音聴力検查. JOHNS $7: 1421 \sim 1430,1991$.

2 ) 岡本牧人: 語音弁別検査. 耳喉頭頸 $65: 23 \sim 30,1993$.

3 ) 田中美郷 : 補聴器適合評価機器の試作に関する研究. 昭和 63年度科学研究費補助金研究成果報告書. 1989.

4) 米本 清: 補聴器適合評価用 CD (TY-89) の特徵. JOHNS $11: 1395 \sim 1401,1995$.

5 ) 竹内義夫 : 聴覚言語障害の検査用音声の選択. 日本音響学 会誌 $41: 719 \sim 722,1985$.

6 ) 竹内義夫 : 自動語音聴力検査装置 (CASA) の開発. 耳鼻臨 床補42：18２3, 1991.

7 ）宮田耕志, 大森孝一, 庄司和彦, 他 : 人工内耳, 補聴器装 用者に対する対話式語音聴力検査. Audiology Japan 39 : 455〜456, 1996.

$$
\left(\begin{array}{l}
\text { 原稿受付 : 平成 } 9 \text { 年 } 11 \text { 月 } 4 \text { 日 } \\
\text { 原稿採択 : 平成 } 9 \text { 年 } 12 \text { 月 } 17 \text { 日 } \\
\text { 別刷請求先 : 宮田耕志 } \\
\text { T } 526-0053 \text { 長浜市宮前町 } 14-7 \\
\text { 長浜赤十字病院耳鼻咽喉科 }
\end{array}\right)
$$

